\title{
What's In The Name Of Management Consultancies? How Celebrity And Reputation Shape Intervention Effectiveness
}

Dietmar Fink, Bonn-Rhein-Sieg University of Applied Sciences, Germany

Bianka Knoblach, WGMB Wissenschaftliche Gesellschaft für Management und Beratung, Germany

\begin{abstract}
This study contributes to the growing body of research concerning management consultancies by linking two previously disparate fields of study: (1) the examination of the effectiveness of consulting interventions and (2) the examination of the social processes that aim to create and legitimize the insights, knowledge and capabilities of management consultancies. We propose that consulting firms accumulate social authority in the course of preintervention discourse processes that is reflected in their reputation and celebrity. With respect to intervention, this social authority affects change recipients' commitment to and compliance with the requirements of change implementation. We test the proposed relationships by conducting a measured variable path analysis of 117 change initiatives in German companies that were set up and implemented with the assistance of external consultancies. Our findings indicate that a consulting firm's levels of both celebrity and reputation affect the change recipients' commitment to proposed change strategies and thus, indirectly affect their behavioral compliance with the explicit requirements of change implementation.
\end{abstract}

Keywords: Management Consulting; Intervention; Reputation; Commitment

\section{INTRODUCTION}

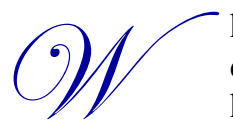

hat's in the name of a company? Over two decades ago, Fombrun and Shanley (1990) addressed this question to pioneer the study of the value-creating role of corporate reputations. Since then, scholars have examined various issues of corporate reputation; they have refined the concept and related it to other intangible assets, such as a firm's status, image, legitimacy and celebrity (e.g., Barron \& Rolfe, 2012; Boyd, Bergh \& Ketchen, 2010; Fombrun, 2012; Foreman, Whetten \& Mackey, 2012; Rindova, Pollock \& Hayward, 2006). Intangible assets like these derive their value from positive collective perceptions. They are termed "social approval assets" by Pfarrer, Pollock and Rindova (2010). Two types of such assets have attracted particular attention in recent studies: a firm's reputation and its celebrity. Several studies have indicated that the possession of these assets affects the activities of organizations from a wide range of industries, such as manufacturing, investment banking, accounting, health care and education (e.g., Fang, 2005; Hibbard, Stockard \& Tusler, 2005; Love \& Kraatz, 2009; Pfarrer et al., 2010; Rauterkus \& Song, 2005; Rindova, Williamson, Petkova \& Sever, 2005). Surprisingly, little attention has been paid to the role of reputation and celebrity in an industry in which the actors claim to give valuable advice to nearly all of the world's most reputable and admired companies (e.g., McKinsey \& Company, 2012): management consultancy. What is the value-creating role of a management consultancy's own reputation and celebrity? How can a consulting firm's social approval assets affect the outcome of an intervention? This study expands the research findings from other industries and suggests that greater awareness of the symbolic authority that a consulting firm's "name" communicates might provide insight that would help to guide its interventions more effectively. Greater awareness might also contribute to the development of an integrated theory of management consulting by bridging the gap between two previously separate streams of consulting research.

The academic study of management consultancies has produced two major schools of thought (e.g., Fincham \& Clark, 2002): (1) intervention theories, which focus on the effectiveness of consulting processes, and (2) discourse theories, which examine the social processes that aim to create and legitimize the insights, knowledge and capabilities of 
management consultancies prior to their actual work with the client. Essentially, these research streams have emerged independently of one another and are therefore usually addressed separately.

Intervention theories are heavily influenced by the organizational development paradigm. This paradigm suggests that a planned, collaborative intervention can facilitate organizational shifts in two fundamental ways: by improving the internal problem-solving capacity of the organization (e.g., Beckhard, 1969; Bennis, 1969; French \& Bell, 1995) and by encouraging learning processes in management (e.g., Schein, 1969; Senge, 1990). Much of the literature on intervention theories has developed around the stages of change and has focused on identifying the optimum number and sequence of stages in the intervention process. The underlying objective of all of these approaches is to enhance the overall effectiveness of an intervention.

Discourse theories, on the other hand, consider the issues addressed by intervention theories as "second-order problems" that only occur when the client has already accepted that a management consultancy has something useful to offer (Fincham \& Clark, 2002). Scholars who follow this school of thought argue that the actual problem faced by management consultancies is first and foremost convincing potential clients of the value of the consultancy's knowledge and abilities (e.g., Alvesson, 1993; Clark, 1995; Starbuck, 1992). Therefore, management consultancies regularly instigate discourse by employing effective rhetoric, primarily through books and articles in business magazines, to propagate new management principles that serve to legitimize the consultancy's expertise (e.g., Kieser, 1997; Legge, 2002). This constant stream of management innovation, it is argued, is designed to create self-reinforcing growth in the market for consulting services (Jackall, 1988).

Unlike the literature on intervention theories, the literature on discourse theories neither addresses the effectiveness of management consultancy work nor aims to improve the success of intervention. This limitation leaves important questions unanswered; questions that are not addressed by intervention theories, either. For example, to what extent is the success of an intervention affected by the prior discourse that produced the intervention? To what extent is the success of an intervention affected by the way in which the consulting firm acted during the relevant discourse? To answer these questions, we must first address the overriding issue of how discourse and intervention theories can be linked. No attempts have been made, to our knowledge, to integrate these two streams of research.

With the present work, we aim to contribute to closing this gap. In the following section, we develop new theoretical arguments concerning the mechanisms by which the level of reputation and celebrity that a consulting firm acquires in the course of pre-intervention discourse processes affects the outcomes of the consulting firm's interventions. To test the proposed relationships, we conduct a measured variable path analysis based on 117 change initiatives that were set up and implemented with the assistance of external consultancies.

\section{THEORY DEVELOPMENT}

\section{The Discourse Framework: Celebrity and Reputation}

The two types of social approval assets that we address in this study - a consulting firm's celebrity and its reputationboth derive their value from favorable collective perceptions (Pfarrer et al., 2010). However, scholars make note of a significant difference between the two concepts: while a consulting firm's celebrity arises largely from emotional resonance, i.e., the excitement and engagement that certain consulting firms generate (Rindova et al., 2006), a favorable reputation - although a positive reputation may also capture some positive emotional effects - is derived primarily from a consulting firm's demonstrated ability to create valuable outputs (Rindova et al., 2005).

The concept of firm celebrity has been developed substantially by Rindova and colleagues (2006). The term refers to those firms that achieve a "high level of public attention" combined with "positive emotional responses from stakeholder audiences" (Rindova et al., 2006: 51). Rindova and colleagues propose that firm celebrity is socially constructed by the media, which cast firms in dramatic narratives in an effort to provide an explanation for the causes of complex and uncertain events. These narratives direct the audience's attention toward the firms that they feature and attract the audience to these firms (Dyer, 1979; Gamson, 1994; Reeves, 1988). In an attempt to create notable narratives that are "creative, novel, original, or unexpected" (McQuail, 1985: 97), the media focus the audience's interest on firms that serve as protagonists of exciting shifts in organizations, industries or society as a whole (Rindova 
et al., 2006). In fact, journalists tend to report on change rather than the status quo (Andreassen, 1987; Lippmann, 1922). Consulting firms are very adept at using this predilection of the media for their own purposes. Through the use of sophisticated rhetoric, consulting firms incorporate their own knowledge, concepts and experience with change processes into the discourse. These aspects are then adopted by the media, "packaged" for specific target groups and disseminated (e.g., Fink, 2003; Kieser, 1997). The media frequently report on the achievements of consulting firms and use them to organize their reports around a central character that takes a leadership role with respect to the challenge of change. By presenting the achievements of a consulting firm as a significant force enabling the implementation of organizational change, the consulting firm becomes a protagonist in the media's dramatic narrative - the character that makes events happen and propels the dramatic action forward (DiYanni, 1990; Smiley, 1971). The use of a consulting firm as a protagonist leads to over-attribution of the success of a change initiative to the actions of the consulting firm, thereby exaggerating the consulting firm's power to stimulate and manage change.

This media-dramatized reality concerning the capabilities of a consulting firm increases the likelihood that the consulting firm will achieve a high level of celebrity through which it may - delibe - rately or otherwise - influence change recipients' personal interpretations of reality (Weick, 1995) in the course of future interventions.

Unlike a consulting firm's celebrity, its reputation does not arise from the dramatic excitement that certain consulting firms generate. Rather, a consulting firm's reputation arises from its demonstrated ability to create valuable results for its clients. Research into reputation adopts a variety of theoretical perspectives. In a comprehensive review, Rindova and colleagues (2005) suggest that a firm's reputation is best referred to as an intangible asset deriving its value from broad public recognition of the high quality of its capabilities and outputs (Deephouse, 2000; King \& Whetten, 2008; Pfarrer et al., 2010). This definition also reflects the practical research into the reputation of consulting firms published by business magazines. These studies operationalize the concept of reputation by using various rankings that capture the recognition that a set of consulting firms has received in a given market or organizational field (e.g., Fink \& Knoblach, 2012; Vault, 2013). Such rankings may focus potential clients' attention on particular consulting firms that are recognized as consistently delivering high-value outputs, thereby reducing the clients' uncertainty, even if they lack direct experience with the respective consulting firms. We propose that this process may result in a greater willingness to comply with the changes advocated by high-reputation consulting firms as opposed to changes advised by low-reputation consulting firms within the context of an intervention.

Drawing on research in intervention theory and psychology, we suggest that a consulting firm's celebrity and reputation do not directly affect the change recipient's actual behavioral support for change, i.e., his or her compliance. Rather, the effects of a consulting firm's celebrity and reputation are mediated by the change recipient's commitment to the proposed organizational realignment. We discuss this aspect in more detail in the following section.

\section{The Intervention Framework: Commitment and Compliance}

According to intervention theories, a major goal of any intervention is to increase an organization's internal commitment to the proposed changes (Argyris, 1970). This is because commitment to change is one of the most important psychological components that determines change recipients' actual behavioral support for or resistance to change initiatives (e.g., Armenakis, Harris \& Field, 1999; Coetsee, 1999; Klein \& Sorra, 1996; Meyer, Srinivas, Lal $\&$ Topolnytsky, 2007). While intervention theories assume that the commitment of the change recipients is essentially influenced by the "correct" number and sequence of intervention stages and by the consultancy's role in the intervention process, we propose that change recipients' commitment is also affected by the way in which the consulting firm has demonstrated its own expertise and capabilities in discourse processes prior to the intervention. We propose that a consulting firm accumulates social authority in the course of pre-intervention discourse processes that is reflected in its reputation and celebrity. With respect to an intervention, this symbolic authority affects the change recipients' commitment to the requirements of change implementation.

Commitment has long been recognized as a key component of the behavioral support of change recipients for organizational realignment (Coetsee, 1999; Conner, 1992; Klein \& Sorra, 1996). Research conducted by Herscovitch and Meyer (2002) has contributed to the substantiation of the claims concerning commitment effects by introducing a multidimensional conceptualization of commitment to change and by examining the relationships between different forms of commitment and employee support for change initiatives. 
Based on previous definitions, Herscovitch and Meyer suggest that commitment to change can be understood as "a force (mind-set) that binds an individual to a course of action deemed necessary for the successful implementation of a change initiative" (2002: 475). This force or mindset can assume different forms that the authors characterize as affective, normative and continuance commitment to change. Affective commitment to change reflects a change recipient's desire to support a change initiative based on a belief in its inherent benefits. Normative commitment to change refers to a change recipient's sense of obligation to provide support for a change initiative. Continuance commitment to change reflects a change recipient's recognition that costs are associated with failure to provide support for the change.

In a set of empirical studies, Herscovitch and Meyer (2002) demonstrate that these three mindsets can be measured and distinguished from one another and from mindsets regarding other workplace commitments. They provide convincing evidence that the three forms of commitment to change are valid predictors of a change recipient's actual behavioral support for change, i.e., his or her compliance.

\section{The Interaction among Celebrity, Reputation, Commitment and Compliance}

Prior research suggests that the three forms of commitment are influenced by affective and cognitive antecedents in different ways (e.g., Kell \& Motowidlo, 2012; Solinger, Van Olffen \& Roe, 2008). In our definitions of celebrity and reputation, we imply that a consulting firm's celebrity is primarily associated with affective resonance in terms of the excitement that the firm generates, whereas a consulting firm's reputation is primarily associated with cognitive beliefs based on an evaluation of its ability to create valuable outputs. That is, we consider celebrity to be primarily related to affection and reputation to be primarily related to cognition. Building on this assumption, we propose that celebrity and reputation influence the different forms of commitment in different ways.

Prior research indicates that affective commitment is essentially responsive to affective causes (Edwards, 1990; Solinger et al., 2008). Consistent with this research, we propose that the affective character of celebrity that arises from the media's dramatic presentation of certain consulting firms as "heroes" who have mastered complex organizational shifts is likely to influence the affective desire of change recipients to support a change strategy proposed by those consulting firms. Media research suggests that such attitude formation may result from affective bonds that media audiences form with celebrities (e.g., Nariman, 1993; Sabido, 1989). This effect has long been used in the advertising and promotion of consumer products. Advertising research indicates that celebrities who are prominently featured in entertainment programs can effectively promote product sales by creating favorable attitudes toward the products that they endorse (e.g., Atkin \& Block, 1983; Kamins, 1990). Similarly, we propose that the celebrity consulting firms that the media features as protagonists of exciting shifts in organizations become role models that can effectively promote organizational realignment. Thus, we propose that a celebrity consulting firm is likely to produce stronger affective commitment on the part of change recipients than a non-celebrity firm. Therefore, we hypothesize the following:

Hypothesis 1: As the celebrity of the consulting firm increases, the affective commitment of change recipients also increases.

This study recognizes, as does prior research, the association of a "desire-like" mindset, such as affective commitment, with precursory affective phenomena, such as the excitement and emotional attraction that celebrity consulting firms create. However, if change recipients with a high level of affective commitment are assumed to support the changes because of their "belief" that such changes will be beneficial, then we must consider a supplementary relation: social psychology research identifies a strong link between beliefs and cognitive processes (e.g., Festinger, 1957). When a change recipient believes in the inherent benefits of a change strategy that is proposed by a particular consulting firm, these cognitive processes will typically have a strong evaluative component (e.g., Jackson, 2002). Such an evaluation is likely to be conducted in a comparative manner, with the prior performance of the firm in question being compared with that of other relevant firms. Therefore, a consulting firm's demonstrated ability to create valuable results (i.e., its reputation) should increase change recipients' belief in the benefits of a change strategy proposed by that firm - and thus, their affective commitment. Accordingly, we hypothesize the following: 
Hypothesis 2: As the reputation of the consulting firm increases, the affective commitment of change recipients also increases.

A change recipient's normative commitment (i.e., his or her obligation to provide support for a change initiative) has been argued to include the cognition-based attitudinal component of commitment (e.g., Solinger et al., 2008). Cognition-based attitudes have been found to be influenced by both affective and cognitive antecedents (Edwards, 1990). Turning to the cognitive antecedents first, previous research indicates that the concepts and ideas that are propagated by high reputation management consultancies can become commonly accepted norms (Fink, 2003). These norms represent a firmly established element of regular business practice that affects change recipients' sense of obligation to support the changes proposed by the consultancies and, therefore, their normative commitment. Popular examples of widespread normative obligation to the ideas of high reputation consultant include Taylor's scientific management approach, developed at the beginning of the $20^{\text {th }}$ century, and the portfolio analysis established by the Boston Consulting Group in the 1970s. Accordingly, we hypothesize the following:

Hypothesis 3: As the reputation of the consulting firm increases, the normative commitment of change recipients also increases.

With regard to the affective antecedents of normative commitment, we must acknowledge that an obligation to a certain behavior typically stems from the recognition of the behavior as a tested, proven, well-established and commonly accepted one. Unlike the reputation of a consulting firm, a consulting firm's celebrity appears to signal nonconformity and creativity rather than established behavior (Rindova et al., 2006). In fact, an association with creative, novel, original or unexpected approaches, as reflected by a consulting firm's celebrity, primarily emphasizes the firm's talent for unconventional thinking. Such unconventional thinking may well produce positive affective reactions on the part of the change recipients, as we stated in Hypothesis 1 . However, we propose that it is unlikely to increase the change recipients' obligation to support changes that are advised by a celebrity consulting firm. Rather, we suggest that the change recipients' obligation to support a change strategy proposed by a consulting firm tends to be lower as the recognition of the firm's outputs deviates from what is being regarded as conventional and commonly accepted-i.e., the more innovative, non-confirmative and celebrity-like a consulting firm appears to be. This is because unconventionality may gratify change recipients but lacks a reference case that legitimizes the respective behavior as being appropriate and auspicious. Therefore, we hypothesize the following:

Hypothesis 4: As the celebrity of the consulting firm increases, the normative commitment of change recipients decreases.

A change recipient's continuance commitment refers to his or her perception that costs are associated with failure to provide support for a change. When a change recipient evaluates the consequences of supportive and non-supportive behavior, he or she uses social information regarding what other change recipients think and how they are likely to act (Salancik \& Pfeffer, 1978). The more likely other change recipients are to oppose to the change, the smaller the perceived individual risk of such opposition will be - and vice versa. In other words, the costs that are associated with any behavior that serves to maintain the status quo are likely to be higher when other change recipients support the change. The relationship between a change recipient's continuance commitment and a consulting firm's reputation therefore appears fairly straightforward: from Hypotheses 2 and 3, it follows that other change recipients are more likely to support a change when it is advised by a high-reputation consulting firm. Accordingly, we hypothesize the following:

Hypothesis 5: As the reputation of the consulting firm increases, the continuance commitment of change recipients also increases.

Following the same argument, the relationship between a change recipient's continuance commitment and a consulting firm's celebrity appears to be ambiguous. While the positive affective resonance to a consulting firm's celebrity is likely to increase the probability that other change recipients will support the firm's advice (Hypothesis 1), the nonconformity that is associated with celebrity is likely to reduce that probability because it reduces change recipients' obligation to provide support (Hypothesis 4). Overall, we expect the latter effect to be more relevant to change recipients' continuance commitment because the perceived risk associated with failure to provide support for a change 
that is deemed to be (solely) obligatory is likely to be higher than the risk associated with failure to provide support for a change that is considered to be (solely) exciting. In fact, change recipients may find it venturesome to follow a change strategy that is advised by a celebrity consulting firm because the firm's unconventionality complicates predictions regarding the strategy's chances of success. Therefore, the higher the consulting firm's level of celebrity, the lower the perceived costs that are associated with non-supportive behavior-and vice versa. Accordingly, we hypothesize the following:

Hypothesis 6: As the celebrity of the consulting firm increases, the continuance commitment of change recipients decreases.

As stated above, we suggest that the commitment of change recipients to a proposed change strategy will mediate the effect of the consulting firm's celebrity and reputation on behavioral compliance with respect to the implementation of the required organizational realignment. This assumption reflects the premise underlying our study that a highreputation celebrity consulting firm's initial support in shaping new managerial perspectives creates symbolic authority that affects the change recipients' commitment to the change strategy. When the changes are to be implemented, this commitment, in turn, encourages supportive behavior and counteracts institutional inertia.

We therefore predict that celebrity and reputation influence the change recipients' supportive behavior indirectly through their effects on the three dimensions of commitment (affective, continuance and normative) to the underlying change strategy. However, the sociological perspective on celebrity and reputation suggests that commitment only partially mediates these relationships and that a consulting firm's celebrity and reputation may also directly influence change recipients' compliance. We tested an alternative model that allowed for this differing view. Both models, consistent with previous research on the relationship between commitment and actual behavioral support for change initiatives, demonstrate that higher levels of each dimension of commitment are associated with higher levels of compliance with the requirements for change (Herscovitch \& Meyer, 2002). Therefore, we hypothesize as follows:

Hypothesis 7: As (a) affective, (b) normative or (c) continuance commitment increases, change recipients' compliance with the requirements for change also increases.

\section{DATA AND METHODS}

\section{Sample and Data Collection}

The study sample consisted of 117 change initiatives that were set up and implemented by German companies with the assistance of external consultancies between June 2007 and January 2011. Of these companies, 61 were from the raw materials or manufacturing industries and 37 companies were from the service sector. The companies' annual turnover ranged from 1.1 billion to 126.9 billion euros. The sample of change initiatives was generated with the assistance of a German-based service organization that regularly collects client feedback on behalf of consulting firms. Each change initiative was evaluated by three change recipients who were responsible for adopting or adapting to changes. The evaluations entailed a standardized questionnaire that were administered at two points in time: (1) immediately after the change initiative had been announced by the company's management (to analyze the change recipients' initial commitment to the change strategy) and (2) three months following the announcement (to analyze the change recipients' actual behavioral support for the implementation of the change initiative). Thus, we collected two sets of evaluations from a total of 351 respondents.

The sample of change initiatives was generated from a total of 149 change projects. To focus our analysis on initiatives that generate significant organizational changes (as perceived by the change recipients), we assessed the respondents' perceptions of the degree of these changes' significance with respect to their organizations using a five-point singleitem measure with anchors ranging from "minor" to "extremely major" (Herscovitch \& Meyer, 2002). Only when all three change recipients classified an initiative's significance rating as "major" or "extremely major" did we consider the initiative in the final analysis. On this basis, 25 change projects were eliminated. We also excluded seven other projects for which one or more respondents had left their companies during the period between the first and second measurement. However, the commitment of the respondents who left their companies did not differ significantly from the commitment of those who remained. 
The consulting firms examined ranged from small, specialized firms with approximately 10 employees to consulting giants, such as McKinsey, Accenture and the Big Four accounting firms: Deloitte, PwC, Ernst \& Young and KPMG. To determine the celebrity and reputation of these consulting firms, we used articles and rankings that were published by three leading German business magazines within a one-year period prior to the announcements of the change initiatives supported by the consulting firms in question. These business magazines were WirtschaftsWoche, Capital and manager magazin, which are the general business publications with the highest circulation in Germany. These magazines publish articles that contain the types of rankings and dramatic narratives that facilitate the generation of reputation and celebrity among consulting firms. We obtained the articles from the LexisNexis and WISO databases.

\section{Measures}

Celebrity. Celebrity is defined as a combination of a high level of public attention that is focused on a consulting firm and positive emotional responses from potential clients and other management audiences. We used both components to create our measure of a firm's celebrity. To address the public attention component of celebrity, we examined the media presence of consulting firms, which we measured by determining the number of articles that referred to each firm in the year prior to the change announcement. This method generated a dataset of 658 articles. Following Pfarrer and colleagues (2010), consulting firms in the top quartile of media presence for a given period were coded 1 for media presence and 0 otherwise. The consulting firm that attracted the greatest coverage, McKinsey \& Company, was mentioned 125 times, whereas the median consulting firm was mentioned only twice, and the bottom quartile of the sample received no coverage at all.

To capture the affective component of celebrity, we manually coded all sampled articles. This process required us to first identify the relevant recording units (Weber, 1990). We defined a recording unit as the assessment of an individual consulting firm's celebrity in a single article. Many articles mention several consulting firms, and a total of 849 recording units were identified. Similarly to prior researchers, we gave each recording unit equal weight in the analysis (e.g., Brown \& Deegan, 1998; Deephouse \& Carter, 2005).

We measured the affective component of celebrity as follows. First, each recording unit was rated positive, negative or neutral (e.g., Dominick, 1981). A recording unit was rated positive when a consulting firm was associated with the benefits of innovative change within a single organization or within an industry as a whole; when a consulting firm was considered to have innovative knowledge or capabilities; when a consulting firm was associated with strategic moves that were described as creative, novel, original or unexpected; or when a consulting firm was praised for pioneering groundbreaking ideas. Positive ratings include assertions such as "McKinsey decodes the DNA of the automotive industry." Contrastingly, a negative rating was assigned when a consulting firm was associated with a devastating change outcome in a single organization or in an industry as a whole or when a consulting firm was criticized for misdirecting future changes. Negative ratings include assertions such as "Germany's solar industry is in bad shape. Solar Millennium went bankrupt. Solon went bankrupt. Q-Cells has nearly used up its equity and has surrendered to its creditors to avert bankruptcy. What two of these firms have in common is not only their demise but also their consultants. First and foremost, the consulting firm Alvarez \& Marsal..." Finally, a neutral rating was assigned when an article included no evaluative assertion with respect to the consulting firm in question or when there was a balance between positive and negative reporting. One author read and coded full-text versions of all sampled articles. The second author coded all articles that were related to the consulting projects conducted between June 2007 and May 2009. We reached agreement on 470 of the 496 recording units (94.8 percent). Additionally, a colleague was instructed to use the same coding scheme on a random sample of 30 articles from 2010 and 2011. We agreed on 93.3 percent of the codes. Together, these results suggest high levels of intercoder reliability (Weber, 1990).

We then calculated the Janis-Fadner (JF) coefficient of imbalance to operationalize the overall affective resonance of each consulting firm's media coverage (Deephouse, 2000; Janis \& Fadner, 1965; Pfarrer et al., 2010; Pollock \& Rindova, 2003). We computed the JF coefficient according to the following formula:

$$
\left(P^{2}-P N\right) / V^{2} \text { if } P>N \text {; } 0 \text { if } P=N \text {; and }\left(P N-N^{2}\right) / V^{2} \text { if } P<N,
$$

where $V$ denotes the total number of articles that refer to a consulting firm in the year prior to the change announcement, $P$ is the number of positive articles, and $N$ is the number of negative articles. The JF coefficients range 
from -1 to 1 , with -1 indicating all negative media coverage and 1 indicating all positive coverage. Similarly to the measure of media presence, we then produced a dummy variable that coded consulting firms with JF scores in the top quartile of positive affective content 1 and others 0 . If a consulting firm was in the top quartile for both media presence and positive affect in the period examined, it was coded 1, indicating celebrity status, and 0 otherwise (Pfarrer et al., 2010).

Reputation. Following prior research on firm reputation (e.g., Fombrun \& Shanley, 1990; Gardberg \& Fombrun, 2002; Love \& Kraatz, 2009; Roberts \& Dowling, 2002), we obtained data concerning the reputations of consulting firms by examining the rankings that have been published in leading business magazines. Specifically, we used the "management consulting" ranking and the "hidden champions" ranking published by manager magazin and Capital. The "management consulting" ranking focuses on the 10 leading management consulting firms in Germany. The "hidden champions" ranking covers small and medium-sized consulting firms. Both rankings use a similar methodology (Lambrecht, 2009; Student, 2012). Top executives and senior managers (including board members, sponsors of consulting projects and project managers) rate the capabilities and outputs of consulting firms by ranking them according to a number of criteria. Examples include the overall level of satisfaction with the results of the consulting firm's work and an evaluation of their expertise in areas such as strategic planning, cost reduction and business process optimization. Although the number of categories examined is different for the "management consulting" and "hidden champions" rankings and although the criteria may vary from year to year even for the same rankings, we believe that these rankings are the best assessment of a consulting firm's reputation at any given point in time.

To calculate the overall reputation scores of the consulting firms, we used the versions of the rankings that were published most recently prior to the beginning of the consulting project in question. If a consulting firm was listed among the top five companies with respect to a particular criterion for one ranking, we coded that firm as having a positive reputation in that category. We then divided the number of positive reputation codes for each consulting firm by the total number of published sub-categories in the rankings to generate an overall reputation score. The scores ranged from 0 to 1 , with 0 indicating that a consulting firm did not appear among the top five firms in any category in a ranking and 1 indicating that the firm appeared among the top five firms in all categories.

Commitment. To measure the change recipients' affective, continuance and normative commitment to the proposed change strategies, we used scales developed by Herscovitch and Meyer (2002). Each scale consisted of six items reflecting the change recipients' possible responses to the change strategy. Examples of items from the affective commitment scale include "I believe in the value of this change" and "This change is a good choice for this organization." Examples from the continuance commitment scale include "I have no choice but to go along with this change" and "I have too much at stake to resist this change." Examples from the normative commitment scale include "I feel a sense of duty to work toward this change" and "I would feel guilty about opposing this change." In our study, the alpha coefficients for the affective, continuance and normative commitment to change scales were $.94, .96$ and .93 , respectively. Because the object of analysis was a single change initiative, we calculated the three commitment scores for each initiative as the average of the individual unit-weighted scale scores provided by the three change recipients who evaluated the initiative.

Compliance. To assess the resistance or supportive behavior of the change recipients, we used a 101-point behavioral continuum that was adopted from the work of Herscovitch and Meyer (2002). The anchor points along the continuum were labeled "active resistance" (0-20), "passive resistance" (21-40), "compliance" (41-60), "cooperation" (61-80) and "championing" (81-100). We provided the participants with a written description of each anchor point using the definitions that were proposed by the authors of the measure (Herscovitch \& Meyer, 2002). ${ }^{1}$

\footnotetext{
${ }^{1}$ Active resistance: "Demonstrating opposition in response to a change by engaging in covert behaviors that are intended to ensure that the change fails." Passive resistance: "Demonstrating opposition in response to a change by engaging in covert or subtle behaviors aimed at preventing the success of the change." Compliance: "Demonstrating minimum support for a change by going along with the change, but doing so reluctantly." Cooperation: "Demonstrating support for a change by exerting effort when it comes to the change, going along with the spirit of the change, and being prepared to make modest sacrifices." Championing: "Demonstrating extreme enthusiasm for a change by going above and beyond what is formally required to ensure the success of the change and promoting the change to others." (Herscovitch \& Meyer, 2002: 478).
} 


\section{Control Variables}

Because the change recipients who evaluated the consulting projects under examination were from different companies and experienced different types of organizational change, we added a change-related control variable, as suggested by Herscovitch and Meyer (2002). The change impact variable had three components: the respondents were asked to assess their perceptions of the influence of the consulting projects on their job performance, organizational climate and non-work lives. We used five-point scales with anchors ranging from a "substantial negative effect" to a "substantial positive effect." The alpha coefficient for this measure was .84. We calculated the score for each project using the average of the individual unit-weighted scale scores of all three change recipients who evaluated the project.

Figure 1. Hypothesized Model

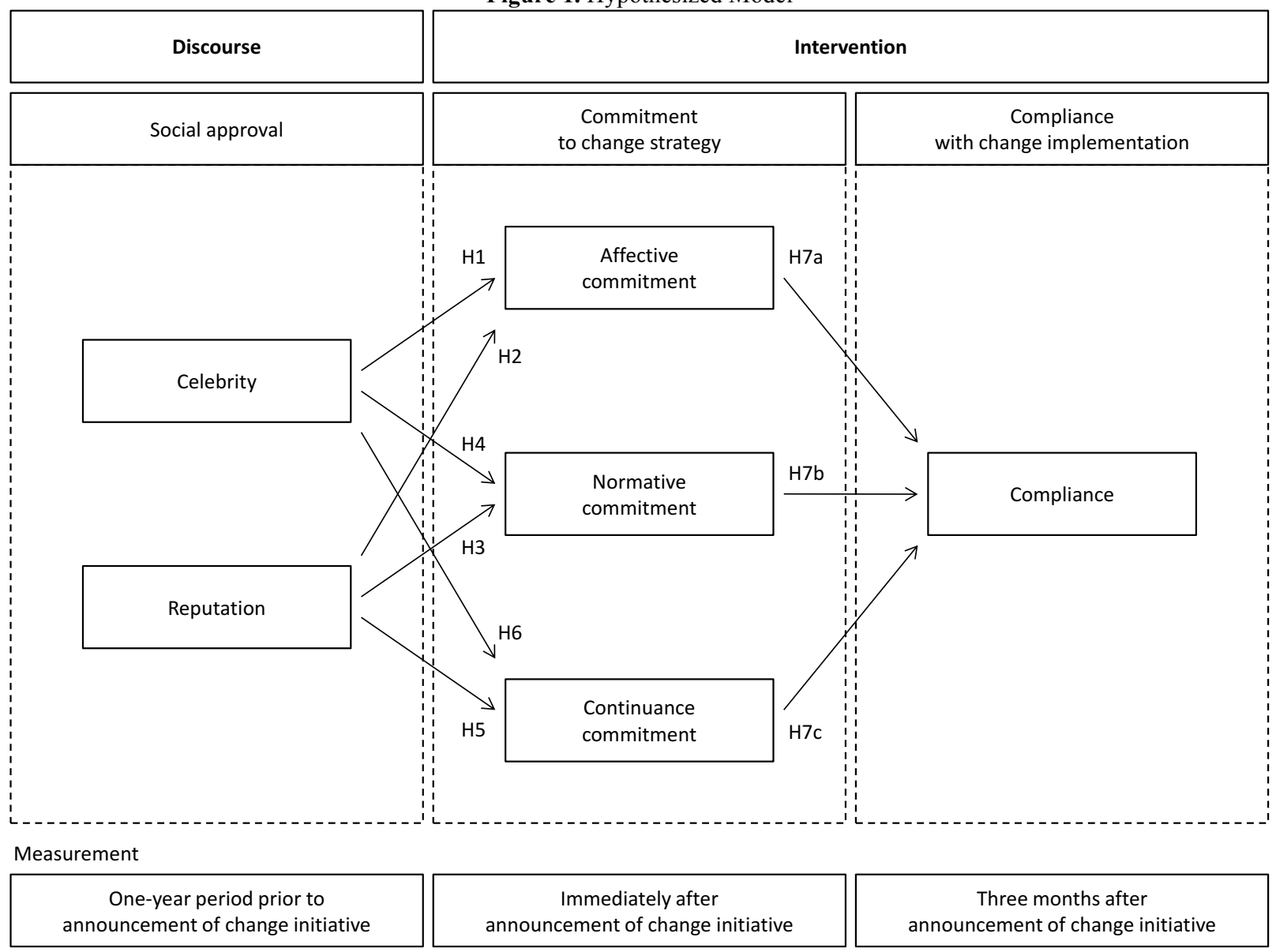

We also controlled for the size of the consulting firms because this variable may influence the social approval of firms (e.g., Fombrun \& Shanley, 1990) and the effectiveness of their interventions (e.g., DeAngelo, 1981). Because the effectiveness of the interventions may also be affected by the size of the client organization (e.g., Nagy, 2005), we also controlled for this variable. We measured both consulting firm size and client firm size in terms of number of employees. Additionally, we included a dichotomous control variable for the industry sector of the client firms. This variable equaled 1 if a client was from the raw materials or manufacturing industries and 0 if a client was from the service industry. 


\section{Analysis}

To test our hypotheses, we conducted a measured variable path analysis using the AMOS 21 software (Arbuckle, 2008). The hypothesized model that is depicted in Figure 1 consists of two exogenous variables and four endogenous variables. Each variable was modeled as a single indicator. The exogenous variables were allowed to co-vary in the estimation of the model. The measured variable path analysis in AMOS provides both an overall assessment of the fit of the hypothesized model to the sample data and tests of the individual hypotheses. We assessed the overall fit of the hypothesized model with the empirical data using the chi-squared statistic, the goodness-of-fit index (GFI), the normed fit index (NFI) and the comparative fit index (CFI). Additionally, AMOS enabled us to compare the hypothesized model to other plausible models by comparing the fit of the alternative models to that of the hypothesized model (Byrne, 2010).

Table 1. Descriptive Statistics and Correlations

\begin{tabular}{|c|c|c|c|c|c|c|c|c|c|c|c|}
\hline Variable & Mean & s.d. & 1 & 2 & 3 & 4 & 5 & 6 & 7 & 8 & 9 \\
\hline $\begin{array}{l}1 \text { Consulting firm } \\
\text { size }\end{array}$ & 564.03 & 906.33 & & & & & & & & & \\
\hline 2 Client firm size & $75,366.50$ & $115,884.96$ & .04 & & & & & & & & \\
\hline 3 Client firm sector ${ }^{a}$ & 0.61 & 0.49 & -.10 & $-.21^{*}$ & & & & & & & \\
\hline 4 Change impact & 8.03 & 3.19 & -.16 & .05 & -.03 & & & & & & \\
\hline 5 Celebrity ${ }^{b}$ & 0.25 & 0.43 & $.26^{* *}$ & -.07 & -.02 & .07 & & & & & \\
\hline 6 Reputation & 0.18 & 0.32 & $.24^{* *}$ & .01 & .04 & -.01 & $.18^{*}$ & & & & \\
\hline $\begin{array}{l}7 \text { Affective } \\
\text { commitment }\end{array}$ & 14.70 & 6.15 & .15 & -.03 & -.10 & .16 & $.55^{* *}$ & .16 & & & \\
\hline $\begin{array}{l}8 \text { Normative } \\
\text { commitment }\end{array}$ & 13.52 & 7.38 & .03 & .01 & .11 & .06 & -.09 & $.42^{* *}$ & -.11 & & \\
\hline $\begin{array}{l}9 \text { Continuance } \\
\text { commitment }\end{array}$ & 18.44 & 7.91 & -.04 & -.10 & -.01 & .01 & .17 & $.24^{* *}$ & $.20^{*}$ & .16 & \\
\hline 10 Compliance & 52.79 & 17.25 & .07 & .07 & -.06 & .11 & .08 & $.23^{*}$ & $.31^{* *}$ & $.35^{* *}$ & $.34^{* *}$ \\
\hline
\end{tabular}

${ }^{\mathrm{a}} 1=$ raw materials and manufacturing, $0=$ service sector, ${ }^{\mathrm{b}} 1=$ celebrity, $0=$ otherwise; $n=117$

$* \mathrm{p}<.05, * * \mathrm{p}, .01$

\section{RESULTS}

\section{Hypothesized Model Evaluation}

Table 1 presents the descriptive statistics and a correlation matrix for the variables used in testing our hypothesized model. Similarly to the findings of Pfarrer and colleagues (2010), the correlation between the celebrity and reputation measures was low $(r=.18, p<.05)$, which indicates good discriminant validity between the two independent variables of the model. Because none of the control variables were significantly correlated with the dependent variables of our model and for the sake of clarity, we did not include the control variables in the path modeling reported here (we calculated a complete path model that included the control variables to confirm that none of these variables had a significant relationship with any of the endogenous variables in our model).

The test of our hypothesized model yielded a chi-squared value of 6.51 with five degrees of freedom and a probability level of .26, which suggests the model's adequate fit with the sample data (see Table 2). To reduce the sensitivity of the chi-squared statistic to sample size, Jöreskog and Sörborn (1993) recommend evaluating model fit based on the ratio of the chi-squared value to the number of degrees of freedom. A ratio that is equal or less than 2 is considered to indicate goodness of fit (Byrne, 2010). In our case, the ratio was 1.30, which indicates good model fit. The GFI, NFI and CFI values of $.98, .95$ and .99 , respectively, are consistent with these findings and thus support our conclusion that the hypothesized model adequately fits the sample data (Hu \& Bentler, 1999). 
The standardized parameter estimates and their significance levels for the hypothesized model are presented in Table 2. As suggested in Hypotheses 1 and 4, a consulting firm's celebrity is significantly and positively related to affective commitment $(\gamma=.53 ; p<.001)$ and significantly and negatively related to normative commitment $(\gamma=$ $-.17 ; p<.05$ ) of change recipients. These findings support our argument that the excitement that some consulting firms generate in the media increases the desire of change recipients to support a change initiative (Hypothesis 1), whereas it reduces their obligation to follow the change (Hypothesis 4). However, a consulting firm's reputation is positively related to both the normative $(\gamma=.45 ; p<.001)$ and continuance commitment $(\gamma=.22 ; p<.05)$ of change recipients. These findings support Hypotheses 3 and 5, and thus, our argument that the demonstrated ability of a consulting firm to produce valuable results influences the obligation of change recipients to support a change.

Table 2. Results of Structural Equation Modeling

\begin{tabular}{|c|c|c|c|c|}
\hline Model & Path & Loading $^{a}$ & Model Fit & Comparison \\
\hline \multirow{9}{*}{$\begin{array}{l}\text { Hypothesized } \\
\text { model }\end{array}$} & Celebrity to affective commitment $(\mathrm{H} 1)$ & $.53^{* * *}$ & $\chi^{2}=6.51$ & - \\
\hline & Reputation to affective commitment $(\mathrm{H} 2)$ & .07 & $d f=5$ & \\
\hline & Reputation to normative commitment (H3) & $.45^{* * *}$ & $p=.26$ & \\
\hline & Celebrity to normative commitment (H4) & $-.17^{*}$ & $\mathrm{GFI}=.98$ & \\
\hline & Reputation to continuance commitment (H5) & $.22^{*}$ & $\mathrm{NFI}=.95$ & \\
\hline & Celebrity to continuance commitment (H6) & .13 & $\mathrm{CFI}=.99$ & \\
\hline & Affective commitment to compliance (H7a) & $.30^{* * *}$ & & \\
\hline & Normative commitment to compliance (H7b) & $.35^{* * *}$ & & \\
\hline & Continuance commitment to compliance $(\mathrm{H} 7 \mathrm{c})$ & $.22^{* *}$ & & \\
\hline \multirow{7}{*}{$\begin{array}{l}\text { Alternative } \\
\text { Model } 1\end{array}$} & Celebrity to affective commitment (H1) & $.55^{* * *}$ & $\chi^{2}=9.09$ & $\Delta \chi^{2}=2.58^{\mathrm{b}}$ \\
\hline & Reputation to normative commitment (H3) & $.45^{* * *}$ & $d f=7$ & $d f=2$ \\
\hline & Celebrity to normative commitment (H4) & $-.17^{*}$ & $p=.25$ & $p>.05$ \\
\hline & Reputation to continuance commitment (H5) & $.24^{* *}$ & $\mathrm{GFI}=.98$ & \\
\hline & Affective commitment to compliance (H7a) & $.30^{* * *}$ & $\mathrm{NFI}=.93$ & \\
\hline & Normative commitment to compliance $(\mathrm{H} 7 \mathrm{~b})$ & $.35^{* * *}$ & $\mathrm{CFI}=.98$ & \\
\hline & Continuance commitment to compliance $(\mathrm{H} 7 \mathrm{c})$ & $.22^{* *}$ & & \\
\hline \multirow{9}{*}{$\begin{array}{l}\text { Alternative } \\
\text { Model } 2\end{array}$} & Celebrity to affective commitment (H1) & $.55^{* * *}$ & $\chi^{2}=4.61$ & $\Delta \chi^{2}=1.90^{\mathrm{b}}$ \\
\hline & Reputation to normative commitment (H3) & $.45^{* * *}$ & $d f=3$ & $d f=2$ \\
\hline & Celebrity to normative commitment (H4) & $-.17^{*}$ & $p=.20$ & $p>.05$ \\
\hline & Reputation to continuance commitment (H5) & $.24^{* *}$ & GFI $=.99$ & $\Delta \chi^{2}=4.48^{\mathrm{c}}$ \\
\hline & Affective commitment to compliance (H7a) & $.37^{* * *}$ & $\mathrm{NFI}=.96$ & $d f=4$ \\
\hline & Normative commitment to compliance (H7b) & $.35^{* * *}$ & $\mathrm{CFI}=.99$ & $p>.05$ \\
\hline & Continuance commitment to compliance (H7c) & $.23^{* *}$ & & \\
\hline & Reputation to compliance & -.01 & & \\
\hline & Celebrity to compliance & -.13 & & \\
\hline
\end{tabular}

Initiative and their recognition that costs will accrue if they fail to do so. Contrastingly, we did not find that the reputation of a consulting firm has a positive effect on the affective commitment of change recipients (Hypothesis 2) or that a firm's celebrity reduces the continuance commitment of change recipients (Hypothesis 6).

Overall, a consulting firm's reputation appears to have a stronger total effect $\left(\gamma_{\mathrm{t}}=.23 ; p<.01\right)$ than the consulting firm's celebrity $\left(\gamma_{\mathrm{t}}=.13 ; p<.01\right)$ on the compliance of change recipients. However, a bootstrapping procedure revealed that the difference is not significant $(p>.05)$. Contrastingly, there is a significant difference between the positive indirect effect of celebrity on compliance, as mediated by affective commitment, and the negative indirect effect, as mediated by normative commitment $(p<.05)$. The same is true for the indirect effects of reputation on compliance, as mediated by normative and continuance commitment $(p<.05)$.

Consistent with Hypotheses $7 \mathrm{a}$ through $7 \mathrm{c}$, all three dimensions of commitment are significantly and positively related to compliance. While the effects of affective $(\mathbb{B}=.30 ; p<.001)$ and normative $\mathbb{B}=.35 ; p<.001)$ commitment are relatively strong, continuance commitment appears to be associated with lower levels of behavioral support ( $\mathbb{R}=.22$; 
$p<.01)$. This result is consistent with the findings of Herscovitch and Meyer (2002); however, the differences are not significant in the present study $(p>.05)$.

Because we obtained high-reputation consulting firms from two different populations for our sample, we tested the robustness of our results by dividing our sample into two sub-groups. The first sub-group includes those consulting firms that qualified for the "management consulting" rankings $(n=48)$; the second sub-group includes the firms that qualified for the "hidden champions" rankings $(n=69)$. We tested the extent to which the factor loadings are equivalent across the two groups by using a CFI difference test (Byrne, 2010; Cheung \& Rensvold, 2002). The results suggest that the factor loadings of our model are invariant with respect to the different populations of high-reputation firms $(\triangle \mathrm{CFI}<.01)$.

\section{Alternative Model Evaluation}

Two sets of modifications to the proposed relationships appear to be reasonable. First, in reviewing the structural parameter estimates of our model, we observe two parameters that are non-significant: those represented in Hypotheses 2 and 5. To ensure parsimony, it appears to be advisable to estimate an alternative model that omits these two structural paths (Alternative Model 1). The standardized parameter estimates, their significance levels and the model fit and comparison statistics for the revised model are presented in the second block of Table 2. To compare Alternative Model 1 to the hypothesized model, we used criteria that were suggested by James, Mulaik and Brett (1982) for examining "nested" models (i.e., pairs of models in which one model can be obtained by constraining the parameters of the other model). Accordingly, a significant reduction in chi-squared values suggests an improvement in the model's fit to the sample data. For Alternative Model 1, however, a chi-squared difference test revealed that the decrease in the chi-squared value is not significant $\left(\Delta \chi^{2}(2)=2.58 ; p>.05\right)$. Nevertheless, Alternative Model 1 appears to be superior to our hypothesized model in terms of scientific parsimony because the hypothesized model contains two additional non-significant parameters and does not fit the data significantly better. The goodness-of-fit indices demonstrate that Alternative Model 1 also fits the data very well $(\mathrm{GFI}=.98 ; \mathrm{NFI}=.93 ; \mathrm{CFI}=.98)$.

A second potential alternative to the relationships that are proposed in the hypothesized model is linked to our assumption that a consulting firm's celebrity and reputation influence the compliance of change recipients only indirectly through their effects on the three dimensions of commitment. However, affective, continuance and normative commitment may only partially mediate these relationships, such that a consulting firm's emotional resonance and its demonstrated ability to produce valuable results may directly influence change recipient compliance. We tested this alternative model (Alternative Model 2) by adding direct links from celebrity and reputation to compliance. The standardized parameter estimates and their significance levels, model fit and comparison statistics are presented in the third block of Table 2. We compared Alternative Model 2 with both the hypothesized model and Alternative Model 1. The chi-squared tests revealed that the differences between the chi-squared values for Alternative Model 2 and the hypothesized model $\left(\Delta \chi^{2}(2)=1.90, p>.05\right)$ and the differences between the values for Alternative Model 2 and Alternative Model $1\left(\Delta \chi^{2}(4)=4.48, p>.05\right)$ are not significant. Moreover, the additional paths that were included in Alternative Model 2 appear to be irrelevant to the model, as evidenced by their lack of statistical significance. Therefore, both the hypothesized model and Alternative Model 1 appear to be superior to Alternative Model 2.

Given the statistical significance of all of the parameter estimates, the good fit of the model and the lack of any substantial evidence of model misfit, we conclude that Alternative Model 1 adequately describes the relationships between a consulting firm's celebrity and reputation and the change recipients' commitment to and compliance with change (see Figure 2). 
Figure 2. Alternative Model 1

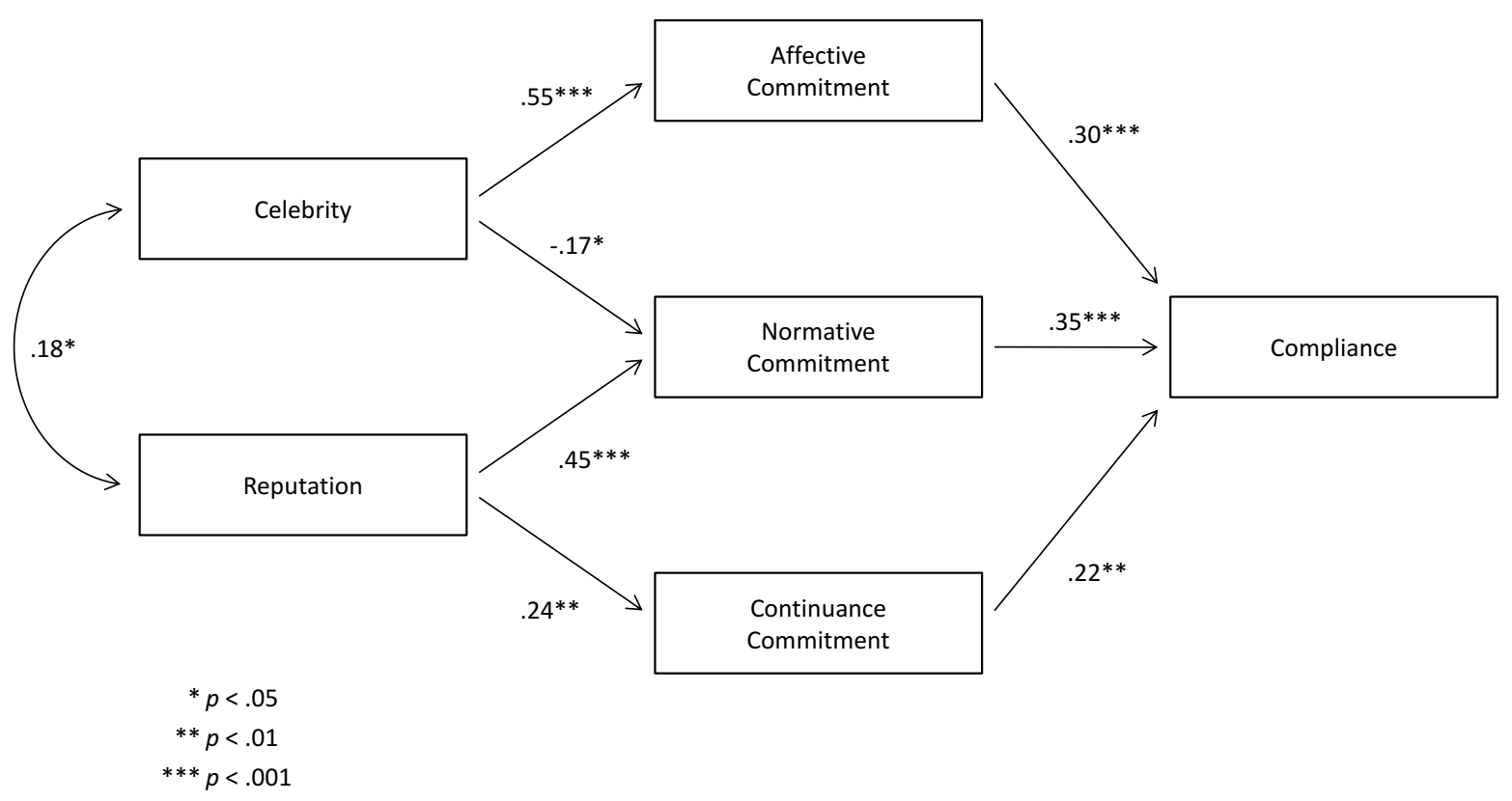

\section{CONCLUSION}

The results of our study strongly support the proposition that the social approval that a consulting firm acquires in the course of management discourse processes that take place prior to the actual intervention creates a solid link between discourse theories and intervention theories. This finding has two key implications for research on management consulting: (1) work on discourse theory can increase its practical value by considering the effects that management discourse has on the effectiveness of actual consultancy projects and (2) work on intervention theories can further narrow down the recommendations for practical application by considering that the result of an intervention is influenced by not only the "optimum" configuration of various stages of the consultancy process and the role that the consultancy adopts in this process but also the social approval that is enjoyed by the consulting firm employed in the form of celebrity and reputation.

Our research indicates that the total effects of a consulting firm's celebrity and reputation on the change recipients' compliance with change do not differ significantly. However, the paths of influence appear to be noteworthy. The strongest single effect of celebrity on the compliance of change recipients is mediated by their affective commitment, whereas the strongest single effect of reputation is mediated by their normative commitment. These results suggest that the behavioral effects of a consulting firm's celebrity and reputation take different "mental routes": a consulting firm's celebrity primarily shapes change recipients' desire to support change initiatives, whereas a consulting firm's reputation primarily influences change recipients' sense of obligation to provide support.

Of even greater significance, however, is that the celebrity of a consultancy can have both positive and negative effects on change recipients' compliance. While the positive effect is mediated by the affective commitment of change recipients, the negative effect takes the mental route via normative commitment. Unlike reputation, the enhancement of which has a sole positive influence on the compliance of change recipients, management consultancies must carefully balance the positive and negative effects of increased celebrity. It would be useful for future research to explore whether the relevant effects actually follow a linear course as proposed in our study or whether any asymmetric relationships exist (e.g., Pierce \& Aguinis, 2013). An asymmetric relationship would be conducive to the calculation of an "optimum ratio" of positive and negative effects: to what extent is it sensible to accept a lower degree of 
normative commitment to the implementation of a change initiative in return for an increased level of affective enthusiasm for the initiative?

With respect to the relationships between the different forms of change recipient commitment and change recipients' actual compliance, our study confirmed the results of Herscovitch and Meyer (2002). All three forms of commitment are significantly and positively associated with compliance. More importantly, however, our findings supported the suggestion that the effects of a consulting firm's reputation and celebrity on the compliance of change recipients are fully mediated by their commitment (i.e., by certain "mindsets" on the part of the change recipients involved). This result emphasizes the symbolic and interpretative nature of an actor's authority that is generated by its social approval assets.

Certain features of this research limit the extent to which the results can be generalized, including the use of a selfreporting measure of behavior, the aggregation of individual-level data and the use of a non-random sample of change initiatives and change recipients. All of these features were the results of conscious decisions because we consider them appropriate for this initial attempt to link discourse theories of management consulting to intervention theories of management consulting. Given the supporting evidence for most of our hypotheses, attempts to replicate the findings using different samples and alternative designs would appear to be warranted.

Certain limitations of our study may provide opportunities for future research. First, an important development in the commitment literature is the recognition that individuals can become committed to many different foci (e.g., Becker, 1992; Reichers, 1985). Indeed, commitment ascribes to organizations and change initiatives (e.g., Herscovitch \& Meyer, 2002) and influences at the organizational level could affect the hypothesized relationships. For example, if initiatives are implemented in an organization with low levels of organizational commitment, one could expect such changes to spill over to particular initiatives, leading to a low base rate of commitment to change and perhaps to a larger gain from the symbolic effects of a consultancy's celebrity and reputation. Contrastingly, if organizational commitment is high, then the commitment level would reduce any potential effects of celebrity and reputation because a significant amount of the variance in commitment to change would be associated with organizational commitment. Therefore, it would be valuable to examine the extent to which the hypothesized relationships are affected by different levels of organizational commitment. Second, the symbolism that is conveyed by a consulting firm's reputation and celebrity may be associated with certain disadvantages that we did not address in our study and that could negatively affect the behavior of change recipients. For instance, a consulting firm's celebrity and positive reputation may distract its clients from the need to ensure compatibility between the consulting firm's knowledge base and the particular change initiative. Future research could explore whether such a distraction may lead to a mismatch between the needs of clients and the advice of consultancies and whether it may thus produce a negative effect on change-related behaviors.

\section{AUTHOR BIOGRAPHIES}

Dietmar Fink is Professor of Management Consulting and Corporate Development at Bonn-Rhein-Sieg University of Applied Sciences and Managing Director of the Society of Management and Consulting Sciences (WGMB) in Bonn, Germany. He holds a PhD in Business Studies from the University of Kassel, Germany, and has been an International Research Fellow at the Oxford University Centre for Corporate Reputation. His research focuses on the management of professional service firms.

Bianka Knoblach is Managing Director of the Society of Management and Consulting Sciences (WGMB) in Bonn, Germany, and Head of the Society's Department of Management and Psychology. She holds a Master in Organizational Psychology from the University of Hagen, Germany, and an MA in Industrial and Organizational Psychology from the University of Wuppertal, Germany. She is a Lecturer of Organizational Psychology and Management Consulting at Bonn-Rhein-Sieg University of Applied Sciences, Germany. Her research focuses on the psychology of reputation and power. 


\section{REFERENCES}

Alvesson, M. (1993). Organizations as rhetoric: Knowledge-intensive firms and the struggle with ambiguity. Journal of Management Studies, 30: 998-1015.

Andreassen, P. B. (1987). On the social psychology of the stock market: Aggregate attributional effects and the regressiveness of prediction. Journal of Personality and Social Psychology, 53: 490-496.

Arbuckle, J. L. (2008). Amos 17.0 user's guide. Chicago, IL: SPSS.

Argyris, C. (1970). Intervention theory and method. Reading, MA: Addison-Wesley.

Armenakis, A. A., Harris, S., \& Field, H. (1999). Paradigms in organizational change: Change agent and change target perspectives. In R. Golembiewski (Ed.), Handbook of organizational behavior: 631-658. New York: Marcel Dekker.

Atkin, C., \& Block, M. (1983). Effectiveness of celebrity endorsers. Journal of Advertising Research, 23: 57-61.

Barron, D. N., \& Rolfe, M. (2012). It ain't what you do, it's who you do it with: Distinguishing reputation and status. In M. Barnett \& T. G. Pollock (Eds.), The Oxford handbook of corporate reputation: 160-178. Oxford: Oxford University Press.

Becker, T. E. (1992). Foci and bases of commitment: Are they distinctions worth making? Academy of Management Journal, 35: 232-244.

Beckhard, R. (1969). Organizational development. Reading, MA: Addison-Wesley.

Bennis, W. G. (1969). The nature of organization development. Reading, MA: Addison-Wesley.

Boyd, B. K., Bergh, D. D., \& Ketchen, D. J. (2010). Reconsidering the reputation-performance relationship: A resource-based view. Journal of Management, 36: 588-609.

Brown, N., \& Deegan, C. M. (1998). The public disclosure of environmental performance information-A dual test of media agenda setting theory and legitimacy theory. Accounting and Business Research, 29: 21-41.

Byrne, B. M. (2010). Structural equation modeling (2nd ed.). New York: Routledge.

Cheung, G. W., \& Rensvold, R. B. (2002). Evaluating goodness-of-fit indexes for testing measurement invariance. Structural Equation Modeling, 9: 233-255.

Clark, T. (1995). Managing consultants. Buckingham, UK: Open University Press.

Coetsee, L. (1999). From resistance to commitment. Public Administration Quarterly, 23: 204-222.

Conner, D. R. (1992). Managing at the speed of change: How resilient managers succeed and prosper where others fail. New York: Villard Books.

DeAngelo, L. E. (1981). Auditor size and audit quality. Journal of Accounting and Economics, 3: 183-199.

Deephouse, D. L. (2000). Media reputation as a strategic resource: An integration of mass communication and resource-based theories. Journal of Management, 26: 1091-1112.

Deephouse, D. L., \& Carter, S. M. (2005). An examination of differences between organizational legitimacy and organizational reputation. Journal of Management Studies, 42: 329-360.

DiYanni, R. (Ed.). (1990). Literature: Reading fiction, poetry, drama, and the essay. New York: McGraw-Hill.

Dominick, J. R. (1981). Business coverage in network newscasts. Journalism Quarterly, 58: 179-185.

Dyer, R. (1979). Stars. London: British Film Institute.

Edwards, K. (1990). The interplay of affect and cognition in attitude formation and change. Journal of Personality and Social Psychology, 59: 202-216.

Fang, L. H. (2005). Investment bank reputation and the price and quality of underwriting services. Journal of Finance, 60: 27292761.

Festinger, L. (1957). A theory of cognitive dissonance. Stanford, CA: Stanford University Press.

Fincham, R., \& Clark, T. (2002). Introduction: The emergence of critical perspectives on consulting. In T. Clark \& R. Fincham (Eds.), Critical consulting: New perspectives on the management advice industry: 1-18. Oxford: Blackwell.

Fink, D. (2003). A life cycle approach to management fashion: An investigation of management concepts in the context of competitive strategy. Schmalenbach Business Review, 55: 46-59.

Fink, D., \& Knoblach, B. (2012). Management consulting 2013. Bonn, Germany: WGMB.

Fombrun, C. J. (2012). The building blocks of corporate reputation: Definitions, antecedents, consequences. In M. Barnett \& T. G. Pollock (Eds.), The Oxford handbook of corporate reputation: 94-113. Oxford: Oxford University Press.

Fombrun, C. J., \& Shanley, M. (1990). What's in a name? Reputation building and corporate strategy. Academy of Management Journal, 33: 233-256.

Foreman, P. O., Whetten, D. A., \& Mackey, A. (2012). An identity-based view of reputation, image and legitimacy: Clarifications and distinctions among related constructs. In M. Barnett \& T. G. Pollock (Eds.), The Oxford handbook of corporate reputation: 179-200. Oxford: Oxford University Press.

French, W. L., \& Bell, C. H. (1995). Organization development: Behavioural science interventions for organizational improvement. Englewood Cliffs, NJ: Prentice-Hall.

Gamson, J. (1994). Claims to fame: Celebrity in contemporary America. Berkeley: University of California Press.

Gardberg, N. A., \& Fombrun, C. J. (2002). The global reputation quotient project: First steps towards a cross-nationally valid measure of corporate reputation. Corporate Reputation Review, 4: 303-307.

Herscovitch, L., \& Meyer, J. P. (2002). Commitment to organizational change: Extension of a three-component model. Journal 
of Applied Psychology, 87: 474-487.

Hibbard, J. H., Stockard, J., \& Tusler, M. (2005). Hospital performance reports: Impact on quality, market share, and reputation. Health Affairs, 24: 1150-1160.

Hu, L., \& Bentler, P.M. (1999). Cutoff criteria for fit indexes in covariance structure analysis: Conventional criteria versus new alternatives. Structural Equation Modeling, 6: 1-55.

Jackall, R. (1988). Moral mazes: The world of corporate managers. New York: Oxford University Press.

Jackson, J. W. (2002). Intergroup attitudes as a function of different dimensions of group identification and perceived intergroup conflict. Self and Identity, 1: 11-33.

James, L. R., Mulaik, S. A., \& Brett, J. M. (1982). Causal analysis: Assumptions, models, and data. Beverly Hills, CA: Sage.

Janis, I. L., \& Fadner, R. H. (1965). The coefficient of imbalance. In H. D. Lasswell, N. Leites, \& Associates (Eds.), Language of politics: 153-169. Cambridge, MA: MIT Press.

Jöreskog, K. G., \& Sörborn, D. (1993). LISREL 8: Structural equation modeling with the SIMPLIS command language. Hillsdale, NJ: Lawrence Erlbaum Associates.

Kamins, M. A. (1990). An investigation into the 'match-up' hypothesis in celebrity advertising: When beauty may be only skin deep. Journal of Advertising, 19: 4-13.

Kell, H. J., \& Motowidlo, S. J. (2012). Deconstructing organizational commitment: Associations among its affective and cognitive components, personality antecedents, and behavioral outcomes. Journal of Applied Social Psychology, 42: 213-251.

Kieser, A. (1997). Rhetoric and myth in management fashion. Organization, 4: 49-73.

King, B. G., \& Whetten, D. A. (2008). Rethinking the relationship between reputation and legitimacy: A social actor conceptualization. Corporate Reputation Review, 11: 192-208.

Klein, K. J., \& Sorra, J. S. (1996). The challenge of innovation implementation. Academy of Management Review, 21: 10551080.

Lambrecht, M. (2009). Auswahl (selection procedure). Capital, 48(6): 114.

Legge, K. (2002). On knowledge, business consultants and the selling of total quality management. In T. Clark \& R. Fincham (Eds.), Critical consulting: New perspectives on the management advice industry: 74-90. Oxford: Blackwell.

Lippmann, W. (1922). Public opinion. New York: Macmillan.

Love, G. E., \& Kraatz, M. (2009). Character, conformity or the bottom line? How and why downsizing affected corporate reputation. Academy of Management Journal, 52: 314-335.

Meyer, J. P., Srinivas, E. S., Lal, J. B., \& Topolnytsky, L. (2007). Employee commitment and support for an organization change: Test of the three component model in two cultures. Journal of Occupational \& Organizational Psychology, 80: $185-211$.

McKinsey \& Company. (2012). About us: Our people. http://www.mckinsey.com/about_us/our_people (accessed on 19 July 2012).

McQuail, D. (1985). The sociology of mass communications. Annual Review of Sociology, 11: 93-111.

Nagy, A. L. (2005). Mandatory audit firm turnover, financial reporting quality, and client bargaining power: The case of Arthur Andersen. Accounting Horizons, 19: 51-68.

Nariman, H. (1993). Soap operas for social change. Westport, CT: Praeger.

Pfarrer, M. D., Pollock, T. G., \& Rindova, V. P. (2010). A tale of two assets: The effects of firm reputation and celebrity on earnings surprises and investors' reactions. Academy of Management Journal, 53: 1131-1152.

Pierce, J. R., \& Aguinis, H. (2013). The too-much-of-a-good-thing effect in management. Journal of Management, 39: 313-338.

Pollock, T. G., \& Rindova, V. P. (2003). Media legitimation effects in the market for initial public offerings. Academy of Management Journal, 46: 631-642.

Rauterkus, S. Y., \& Song, K. (2005). Auditor's reputation and equity offerings: The case of Arthur Andersen. Financial Management, 34: 121-135.

Reeves, J. L. (1988). Television stardom: A ritual of social typification. In J. W. Carey (Ed.), Media, myths, and narratives: Television and the press: 146-160. Newbury Park, CA: Sage.

Reichers, A. E. (1985). A review and reconceptualization of organizational commitment. Academy of Management Review, 10: 465-476.

Rindova, V. P., Pollock, T. G., \& Hayward, M. L. A. (2006). Celebrity firms: The social construction of market popularity. Academy of Management Review, 31: 50-71.

Rindova, V. P., Williamson, I. O., Petkova, A. P., \& Sever, J. M. (2005). Being good or being known: An empirical examination of the dimensions, antecedents, and consequences of organizational reputation. Academy of Management Journal, 48: 1033-1049.

Roberts, P. W., \& Dowling, G. R. (2002). Corporate reputation and sustained superior performance. Strategic Management Journal, 23: 1077-1093.

Sabido, M. (1989). Soap operas in Mexico. Paper presented at the Entertainment for Social Change Conference, University of Southern California, Annenberg School for Communication, Los Angeles.

Salancik, G. R., \& Pfeffer, J. (1978). A social information processing approach to job attitudes and task design. Administrative Science Quarterly, 23: 224-253. 
Schein, E. H. (1969). Process consultation: Its role in organization development. Reading, MA: Addison-Wesley.

Senge, P. M. (1990). The fifth discipline: The art \& practice of the learning organization. New York: Doubleday Currency.

Smiley, S. (1971). Playwriting: The structure of action. Upper Saddle River, NJ: Prentice-Hall.

Solinger, O., Van Olffen, W., \& Roe, R. A. (2008). Beyond the three-component model of organizational commitment. Journal of Applied Psychology, 93: 70-83.

Starbuck, W. H. (1992). Learning by knowledge-intensive firms. Journal of Management Studies, 29: 713-740.

Student, D. (2012). Die Methode (Method). Manager Magazin, 25(12): 50-51.

Vault. (2013). Vault consulting 50. http://www.vault.com/rankings-reviews/company-rankings/consulting/vault-consulting50.aspx (accessed on 19 July 2013).

Weber, R. P. (1990). Basic content analysis (2nd ed.). Newbury Park, CA: Sage.

Weick, K. E. (1995). Sensemaking in organizations. Thousand Oaks, CA: Sage. 
NOTES 